\title{
Studia
}

SYNCHRONICZNE I DIACHRONICZNE ASPEKTY BADAŃ POLSZCZYZNY

www.wnus.edu.pl/sj | DOI: 10.18276/sj.2019.18-06 | 75-89

\author{
IZABELA KĘPKA
}

ORCID: 0000-0001-5779-2617

Uniwersytet Gdański, Gdańsk

izabela.kepka@ug.edu.pl

\section{Obraz Boga w Raju Jacka Kaczmarskiego}

\author{
Słowa kluczowe \\ język poezji Jacka Kaczmarskiego, językowa kreacja, obraz Boga
}

Keywords

the language of the poetry of Jacek Kaczmarski, linguistic creation, image of God

Bóg, jako Istota Najwyższa, transcendentna, obecny jest w języku i literaturze polskiej od początku ich istnienia ${ }^{1}$. Z licznych badań nad obrazem Boga w kulturze polskiej wynika, że do XVIII wieku funkcjonuje dobrze zakorzeniony w tradycji obraz Boga Stwórcy, Króla, Sędziego i Ojca, pozostającego w trwałym kontakcie ze swoim stworzeniem, sprawiedliwego i wysłuchującego próśb ludzi - władcy i sędziego ${ }^{2}$. Swoista atmosfera intelektualna okresu oświecenia sprzyjała pojawieniu się nowych konceptualizacji Boga. Była to z jednej strony koncepcja Boga Sprawcy i Stworzyciela, czuwającego jedynie nad sprawnym

\footnotetext{
${ }^{1}$ Zob. np. Maria Karpluk, „O najwcześniejszym polskim słownictwie chrześcijańskim”, w: O języku religijnym. Zagadnienia wybrane, red. Maria Karpluk, Jadwiga Sambor (Lublin: Wydawnictwo Katolickiego Uniwersytetu Lubelskiego, 1988), 89-101; taż, „O staropolskiej terminologii chrześcijańskiej (inspiracje czeskie)", w: Tysiac lat polskiego stownictwa religijnego, red. Bogusław Kreja (Gdańsk: Wydawnictwo Uniwersytetu Gdańskiego, 1999), 29-33; Edward Klich, Polska terminologia chrześcijańska (Poznań: Poznańskie Towarzystwo Przyjaciół Nauk, 1927).

2 Teresa Kostkiewiczowa, „Jak poeci polscy drugiej połowy XVIII wieku mówili o Bogu i szatanie”, w: Tysiąc lat, 83-98; zob. też: Wojciech Ryszard Rzepka, Bogdan Walczak, „Bóg i szatan w polszczyźnie XVI wieku”, w: Tysiac lat, 57-66; Monika Strykowska, „Obraz Boga w Rytmach Mikołaja Sępa Szarzyńskiego na tle prądów ideowych epoki”, w: Tysiąc lat, 67-82.
} 
funkcjonowaniem mechanizmu, Wiecznej Mądrości, niedostępnej ludzkiemu rozumowi i sercu, z drugiej - Istoty roztopionej w widzialnej naturze, jako „powszechność przedwieczna", podlegającej nieustannemu ruchowi i przemianom w różnych formach materii. Jednak, prócz tych nowych koncepcji, w kulturze obecny jest ciągle obraz Boga znany od początku polskiego piśmiennictwa ${ }^{3}$.

Bóg romantyków to Bóg chrześcijański, którego wyobrażenie zgodne jest z obrazem biblijnym ${ }^{4}$. Klęska powstania listopadowego spowodowała rozpacz Polaków i oskarżanie Boga. Po upadku powstania wielu romantyków utraciło wiarę, twierdziło, że „niebo jest

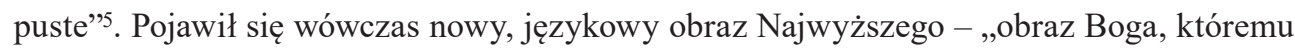
się ludzie opierają, któremu nie ufają, nad którego się wywyższają, którego przeklinają i zabijają - ale czynią to najczęściej z podszeptów szatana, kiedy ulegają jego wpływom, a czasem, dlatego, że są niedojrzali"’.

Znacznie bardziej zróżnicowana, choć stale obecna, jest kreacja Boga w literaturze Młodej Polski. Jak pisała Maria Podraza-Kwiatkowska: „Rozpiętość jest ogromna: od obojętnej wobec ludzi siły, despotycznie rządzącej nie najlepiej stworzonym światem, po przenikającą całe stworzenie miłość. Od groźnego Sędziego po poczciwego Staruszka-Gazdę. Od otaczającej Boga scenerii kosmicznej z gwiazdami, kometami i apokaliptycznym Sądem Ostatecznym po szumiący potok, drewnianą ławkę i zarośnięty macierzanką parów"7. Taka różnorodność występuje w literaturze do dzisiaj. Jak pisała Anna Pajdzińska: „w powojennej poezji nie znajdziemy jednej odpowiedzi na pytanie, jaki jest Bóg. Jawi się On wielorako". Ta różnorodność obrazowania wynika m.in. z sytuacji ludzkiej powodującej czyjś bunt, wątpienie, uwielbienie itd. ${ }^{9}$

Mimo coraz bardziej zróżnicowanej kreacji Boga w historii literatury polskiej, należy podkreślić, że Jego idiolektalny obraz ukazany w literaturze jest obrazem potocznym, ale zawsze ukształtowanym $\mathrm{w}$ ramach religii chrześcijańskiej ${ }^{10}$. Obraz ten jest zawsze mocno spersonifikowany, ponieważ świat opisywany jest za pomocą słów, których znaczenia potrafią nazwać jedynie to, co dla człowieka zrozumiałe. Boga, jako Istotę Najwyższą, transcendentną, należącą do sfery sacrum, człowiek nie jest w stanie ogarnąć rozumem, zatem Jego obraz może (i musi) zawierać tylko takie elementy, które potrafimy nazwać

\footnotetext{
${ }^{3}$ Kostkiewiczowa, ,Jak poeci”, 96.

4 Jadwiga Puzynina, ,Językowy obraz Boga w poezji romantycznej”, w: Tysiąc lat, 115.

${ }^{5}$ Marta Piwińska, „Bóg utracony, Bóg odnaleziony”, w: Problemy polskiego romantyzmu, seria I, red. Maria Żmigrodzka, Zofia Lewinówna (Wrocław: Zakład Narodowy im. Ossolińskich, Wydawnictwo Naukowe PAN, 1971), 251-301.

${ }^{6}$ Puzynina, ,Językowy obraz”, 115.

${ }^{7}$ Maria Podraza-Kwiatkowska, „Obraz Boga wśród światopoglądowych przemian Młodej Polski”, w: Tysiac lat, 155.

${ }^{8}$ Alina Pajdzińska, ,Językowy obraz Boga i szatana w polskiej poezji powojennej”, w: Tysiac lat, 175.

9 Tamże.

10 Jolanta Kowalewska-Dąbrowska, Językowy obraz Boga i człowieka w poezji Jana Twardowskiego (Gdańsk: Wydawnictwo Uniwersytetu Gdańskiego, 2006), 56.
} 
i zrozumieć ${ }^{11}$. O antropologicznych cechach Boga świadczą m.in. próby Jego opisu w katechizmach Kościoła katolickiego, np. w KKK z 1994 roku wyjaśnienie pojęcia Boga dokonuje się poprzez objaśnianie poszczególnych sformułowań zawartych w Credo ${ }^{12}$. O „ludzkiej” naturze Boga świadczą również określenia Jego wielkości i majestatu, będące jednocześnie stereotypowymi ${ }^{13}$ wyobrażeniami: Bóg Król, Bóg Sędzia, Bóg Ojciec, Bóg Stwórca.

Potoczne wyobrażenie Boga w sposób prosty, a jednocześnie zawierający najważniejsze cechy, przedstawiła Anna Wierzbicka: „Bóg to ktoś, kto nie jest częścią świata i od czyjej woli wszystko zależy"14.

W kolejnych badaniach poświęconych pojęciu Boga, Wierzbicka uszczegółowiła swoją propozycję:

Bóg to ktoś (nie coś);

ten ktoś jest kimś dobrym;

nie jest kimś takim, jak ludzie;

nie ma nikogo innego, jak ten ktoś;

ten ktoś zawsze istnieje;

wszystkie rzeczy istnieją, bo ten ktoś chce, żeby istniały;

ludzie istnieją, bo ten ktoś chce, żeby istnieli;

ten ktoś istnieje, bo ten ktoś istnieje, nie z żadnego innego powodu;

ten ktoś żyje $\mathrm{e}^{15}$.

Cechy Boga wymienione przez Wierzbicką są zbieżne z Jego obrazem przedstawionym w KKK, w którym czytamy m.in.:

Bóg nieskończenie doskonały i szczęśliwy zamysłem czystej dobroci, w sposób całkowicie wolny, stworzył człowieka, by uczynić go uczestnikiem swego szczęśliwego

11 Problem ten poruszają również twórcy Katechizmu Kościoła Katolickiego: „Ponieważ nasze poznanie Boga jest ograniczone, ograniczeniom podlega również nasz język, którym mówimy o Bogu. Nie możemy określać Boga inaczej, jak tylko biorąc za punkt wyjścia stworzenie, i to tylko według naszego ludzkiego, ograniczonego sposobu poznania i myślenia”, dostęp 25.05.2018, http://www.archidiecezja.pl/include/ user_file/kkk.pdf.

12 Zob. Katechizm Kościoła Katolickiego (Poznań: Wydawnictwo Pallotinum, 1994), 58-104.

13 Stereotyp rozumiem, jak Jerzy Bartmiński, jako ,subiektywnie determinowane wyobrażenie przedmiotu obejmujące zarówno cechy opisowe, jak i wartościujące obraz, oraz będące rezultatem interpretacji rzeczywistości w ramach społecznych modeli poznawczych” (Jerzy Bartmiński, „Podstawy lingwistycznych badań nad stereotypem - na przykładzie stereotypu matki”, Język a Kultura 12: Stereotyp jako przedmiot lingwistyki. Teoria, metodologia, analizy empiryczne, red. Janusz Anusiewicz, Jerzy Bartmiński (Wrocław: Wydawnictwo Uniwersytetu Wrocławskiego, 1998), 63-83.

14 Anna Wierzbicka, Kocha, lubi, szanuje. Medytacje semantyczne (Warszawa: Wiedza Powszechna, 1971), 22.

15 Cyt. za: Kowalewska-Dąbrowska, Językowy obraz, 57. Por. Anna Wierzbicka, Co mówi Jezus? Objaśnienia przypowieści ewangelicznych w słowach prostych i uniwersalnych, przeł. Izabela Duraj-Nowosielska (Warszawa: Wydawnictwo Naukowe PWN, 2002), 34-40. 
życia. Dlatego w każdym czasie i w każdym miejscu jest On bliski człowiekowi. Powołuje go i pomaga mu szukać, poznawać i miłować siebie ze wszystkich sił. Wszystkich ludzi rozproszonych przez grzech zwołuje, by zjednoczyć ich w swojej rodzinie w Kościele. Czyni to przez swego Syna, którego posłał jako Odkupiciela i Zbawiciela, gdy nadeszła pełnia czasów. W Nim i przez Niego Bóg powołuje ludzi, by w Duchu Świętym stali się Jego przybranymi dziećmi, a przez to dziedzicami Jego szczęśliwego życia ${ }^{16}$.

Można więc ustalić katalog podstawowych cech Boga, zbieżnych w ujęciu katechizmowym i potocznym, sformułowanym przez Wierzbicką. Należą do nich: doskonałość, miłość, dobroć, wieczność, stwórczość i istotowa odrębność od wszelkiego stworzenia (także człowieka).

Jacek Kaczmarski w spektaklu Raj (1980-1981), korzystając z wątków biblijnych, opisał historię świata od chwili jego stworzenia aż po apokalipsę. Cykl ten składa się z 15 utworów, a jego głównymi bohaterami są: Bóg, człowiek oraz aniołowie. Sposób przedstawienia przez poetę tych postaci jest niezwykle interesujący. Kreacja ta, jak często u Kaczmarskiego, wymyka się wszelkim stereotypom i zaskakuje odbiorców niecodziennością przekazu ${ }^{17}$. W artykule przedstawiona zostanie wizja Boga opisana w tym zbiorze. Można ją nazwać „językową kreacją” lub ,idiolektalnym obrazem”. Przypomnijmy za Elżbietą Skorupską-Raczyńską, że językowa kreacja to

[...] tworzenie w dziele literackim wizerunku kogoś i/lub czegoś przez jego autora, antropocentrycznie postrzegającego opisywaną, odtwarzaną i/lub tworzoną rzeczywistość, posiadającego właściwe mu, osobnicze zasoby słownikowe i umiejętności odpowiedniego stylistycznie ich wykorzystywania. Wynikiem (efektem) tej językowej kreacji jest wytwór w postaci artystycznego dzieła (tekstu) literackiego, które dekodowane przez odbiorcę daje możliwość konceptualizacji przedstawionej tam rzeczywistości, zgodnie z jego możliwościami, naturalnymi predyspozycjami (jak wyobraźnia) oraz nabytymi umiejętnościami (jak przygotowanie językowe), a także zarejestrowanymi w pamięci doświadczeniami ${ }^{18}$.

\footnotetext{
${ }^{16}$ Katechizm Kościoła Katolickiego, dostęp 25.05.2018, http://www.archidiecezja.pl/include/user_file/ kkk.pdf.

${ }^{17}$ Por. np. Izabela Kępka, „Językowa kreacja psa i jej funkcje w poezji Jacka Kaczmarskiego”, Studia Językoznawcze. Synchroniczne i diachroniczne aspekty badań polszczyzny, 16 (2017), 135-138; taż, „Gdy królewską godność zachowały tylko kamienne lwy..., czyli o językowej kreacji lwa w piosenkach Jacka Kaczmarskiego", Poznańskie Studia Polonistyczne. Seria Językoznawcza 24 (2017) 2: 59-86.

${ }^{18}$ Elżbieta Skorupska-Raczyńska, Kreacja ojca w powieściach nadniemeńskich Elizy Orzeszkowej (studium językowo-stylistyczne) (Gorzów Wielkopolski-Szczecin: Wydawnictwo Naukowe Państwowej Wyższej Szkoły Zawodowej, 2013), 22-23. Pojęcie językowej kreacji świata wprowadziła T. Skubalanka, która rozumiała ją jako „całokształt procesów językowych, stworzonych przez twórcę tekstu, w pewnym celu; tyle co określony byt fikcjonalny, będący cząstką wizji świata artysty”, zob. Teresa Skubalanka, Językowa kreacja Jacka Soplicy (Księdza Robaka), w: taż, Mickiewicz, Stowacki, Norwid. Studia nad językiem i stylem (Lublin: Wydawnictwo UMCS, 1997), 20.
} 
Podobną koncepcję zaprezentowała Anna Kadyjewska, która analizując pisma Cypriana Kamila Norwida, rozróżniła trzy pojęcia: językowy obraz świata, tekstowy obraz świata i idiolektalny obraz świata. Językowy obraz świata to pojęcie odnoszące się do uogólnionego obrazu świata, tekstowy obraz świata dotyczy konkretnego obrazu świata zawartego w określonym tekście, zaś idiolektalny obraz świata jest pojęciem pośrednim, bo odnoszącym się do obrazu rzeczywistości wyinterpretowanym z wielu tekstów jednego autora ${ }^{19}$.

W niniejszym artykule posługiwać się będę pojęciem językowej kreacji, choć określenie idiolektalny obraz można uznać za synonimiczne.

\section{Bóg Stwórca}

Bóg charakteryzowany jest u Kaczmarskiego za pomocą różnych środków językowych. Na Jego wybrane cechy wskazują użyte w utworach nazwy: Bóg, Stwórca i Pan Zastępów. Określenia są stereotypowe, wywodzące się z Biblii, nazywające Istotę Najwyższą i jedyną. Dodać należy, że w Raju nie ma koncepcji Boga Trójjedynego, choć w jednym z utworów pojawia się postać Chrystusa ${ }^{20}$. Obraz uzupełniony jest określeniem jego królewskiego stroju: A szaty Pana mieniły się złotem. Jak podaje Słownik symboli Władysława Kopalińskiego, złoto symbolizuje m.in. boskość, nieśmiertelność, majestat, królewskość ${ }^{21}$.

Znacznie ciekawszy jest u Kaczmarskiego sposób mówienia o Bogu. W pierwszym tekście zbioru (Stworzenie świata) Bóg sam mówi o sobie w pierwszej osobie liczby pojedynczej, w przeciwieństwie do Biblii, gdzie Bóg mówi o sobie w pierwszej osobie liczby mnogiej - pluralis maiestatis, mającym podkreślić wielkość osoby (np. Rdz 1, 26).

Forma pierwszej osoby liczby pojedynczej nadaje wypowiedzi charakter sprawozdania, które Bóg zdaje ze swojej pracy. Opisy tych działań mają charakter personifikujący, prezentują Jego działania, zachowania i mentalność (oddzieliłem, nadałem kształt, zdecydowałem co dobre ma być co złe). Jednocześnie Bóg sam wartościuje siebie i swoje dzieło. Stwierdzenie uznałem dzieło swe za mądre jest refrenem występującym w prawie wszystkich strofach utworu. Sam więc nazywa jedną ze swoich podstawowych cech - madrość. Ponadto w utworze Stworzenie świata pojawiają się stereotypowe obrazy Boga - Stwórcy i Króla:

\footnotetext{
${ }^{19}$ Anna Kadyjewska, „Problematyka obrazu świata w badaniach języka pisarza na przykładzie pism Cypriana Norwida”, w: Semantyka tekstu artystycznego, red. Anna Pajdzińska, Ryszard Tokarski (Lublin: Wydawnictwo UMCS, 2001), 321-332.

${ }^{20}$ Jest to utwór Chrystus i kupcy. Należy jednak zauważyć, że choć opisane tu zdarzenie odwołuje się do historii z Nowego Testamentu (J 2, 14-16), postać Chrystusa nie ma cech boskich. Został przedstawiony jako człowiek, którego krzyku nikt nie słyszy, nikt też nie przejmuje się jego gniewem.

${ }^{21}$ Władysław Kopaliński, Stownik symboli (Warszawa: Wiedza Powszechna, 1991), 495-496.
} 
(2) Panować światu to sekrety mnożyć

[...] sypnąem gwiazdy w ciemność ziemskiej nocy (99) 22

(3) przepych określa panowania zasięg

[...] Niebo ozdabiam w klucze plemion ptasich

Ożywiam morskie dna

Ptak się upaja traw rozgrzanych swadem

Wszelki stwór morski wśród fal się przewraca (100)

(4) I nie ma władzy bez czci i pokory

Poszły zwierzęta dzikie w ziemskie bory

I człowiek taki jak ja (100)

Co prawda kolejność stwarzania jest taka sama jak w biblijnym poemacie z Księgi Rodzaju (Rdz 1, 1-2, 4), jednak kreacja Boga w utworze Kaczmarskiego częściowo tylko nawiązuje do biblijnej. Wspaniałość i bogactwo tworzonego świata określa ciąg metafor pokazujących doskonałość stworzenia, a przez to również samego Stwórcy (sypnąem gwiazdy w ciemność ziemskiej nocy; Niebo ozdabiam w klucze plemion ptasich; Ożywiam morskie dna [...] / Wszelki stwór morski wśród fal się przewraca). Wierzbicka wymieniała: „Bóg jest jedyny, a wszystkie rzeczy i ludzie istnieją, bo ten On chce, żeby istniały, nie jest kimś innym, niż ludzie, nie można powiedzieć, że nie ma nikogo takiego, jak On"23. Bóg Biblijny, tworząc człowieka, mówi: „Uczyńmy człowieka na Nasz obraz, podobnego Nam” (Rdz 1, 26), Stwórca z utworu Kaczmarskiego nie mówi o podobieństwie człowieka do niego, mówi o ich identyczności (człowiek taki jak ja). Co więcej, o ile w Biblii zaimki Nasz i Nam pisane są wielką literą, czyli tak, jak zwykle pisze się o Bogu, o tyle w Stworzeniu świata Kaczmarskiego zaimek ja, którym Bóg określa siebie, pisany jest małą literą, będącą w tym wypadku dopełnieniem tej koncepcji zrównania Stwórcy z Jego dziełem. Bóg taki jak człowiek jest co prawda Panem Zastępów i gospodarzem raju, ale jego cechy nie różnią się od ludzkich. Bóg tak jak człowiek pragnie śpiewać ze szczęścia (A sam Bóg pośród stug gdyby mógt / to by śpiewał że [...] świat się stat), tak jak człowiek podejmuje gości. Leksyka opisująca sceny z balu u Boga należy do sfery profanum: stót, parkiet, uśmiechy szerokie, śpiew, szał, Bóg poszedt sobie, co sprawia, że również Bóg postrzegany jest jako zwykły człowiek. O Jego bóstwie świadczą jedynie stereotypowe określenia: Bóg, Stwórca oraz fraza: Stwórca [...] pozostawił nam stól, parkiet i świat. To zaskakujące zachwianiem proporcji zestawienie zmienia postrzeganie Boga i przywraca mu jego podstawowe atrybuty Stwórcy (którego dziełem jest świat) i Króla.

\footnotetext{
22 Wszystkie cytaty pochodzą z: Jacek Kaczmarski, Antologia poezji, red. Krzysztof Nowak (Warszawa: Demart, 2012). Po cytacie w nawiasie podaję stronę, z której pochodzi fragment.

${ }^{23}$ Wierzbicka, Co mówi Jezus?, 34.
} 


\section{Bóg Król}

Stereotyp Króla przedstawia sam Bóg za pomocą sentencji podkreślających Jego mądrość i przenikliwą wszechwiedzę: Panować światu to sekrety mnożyć; nie ma władzy bez czci i pokory; przepych określa panowania zasięg. Wizja władzy zawarta została w leksemach: cześć, pokora, przepych ${ }^{24}$, charakteryzowana jest także przez słownictwo określające postawę poddanych: postuszeństwo, uległość, które wymienia Ewa po wygnaniu z raju:

(5) Chodziteś po dolinach i ogrodach

Najdoskonalszy swego władcy twór

Kwiatowy pyt osiadat ci na stopach

Twarz chtodzil tresowany wiatr [...]

A w zamian za to tylko postuszeństwo

Ulegtość wobec Pana więcej nic

Tylko pokora (106)

Te cechy, których Król wymaga od swoich poddanych, wiążą się z postawą uniżenia, poddania się woli, z karnością, powolnością, a więc z właściwościami wykluczającymi wolność, którą deklarował Bóg, stwarzając człowieka takiego jak On sam, który myśli ma swobodne.

Bóg Kaczmarskiego koncentruje swoją władzę na ludziach, im zostawiając panowanie nad innymi stworzeniami (co zresztą zgodne jest z biblijnym obrazem stworzenia - Rdz 1, 26-27). Taki podział władzy widać już w pierwszym utworze (Stworzenie świata), w którym Bóg wyraża swoją wolę w formie deklaracji:

(6) Oto porzadek nie do zastapienia

Wszelkie istnienie żyje swoim torem

Człowiek panuje wszelkiemu istnieniu

Władzę nad soba uznając z pokora (100)

Wyrażenie porządek nie do zastapienia określa reguły wyznaczone przez Stwórcę dla właściwego funkcjonowania wszechświata. Pierwotny ład i harmonia, które zapanowały po zakończeniu tworzenia, Bóg określił mocno wartościującym epitetem rajski świat (Stworzywszy w tydzień rajski świat / Odpoczywatem przez cały dzień siódmy). Zasady, które wyznaczył Stwórca, są warunkiem harmonii świata, ich łamanie spotkać się zatem musi z interwencją Króla. Jednak ta koncepcja władzy Boga jest niepełna. W dalszej części cyklu zawarty jest obraz Boga zazdrosnego o swoją władzę i potęgę, knującego przeciw człowiekowi, Boga, który zataił przed ludźmi prawdę o nich samych, a której konsekwencje są straszne:

${ }^{24}$ O przepychu świadczy sama doskonałość rajskiego świata, o którym była mowa wyżej, a także opis mieniących się złotem szat Boga. 
(7) Człowiek zagładę nosi $w$ duszy

Wystarczy go przerazić

Odbiorę bratu brata język

I koniec zgody Ttumiąc głos

Będa się zdradzać [...]

Na mnie polegać we mnie wierzyć (110)

Metafora Człowiek zagładę nosi w duszy ukazuje nieznaną prawdę o stworzeniu. Bóg Stwórca skalał już na początku duszę człowieka zagładą, co w kontekście wielokrotnie powtarzanego zdania z czasownikiem w pierwszej osobie liczby pojedynczej: Po czym uznałem dzieło swe za mądre, czyni z Boga Stwórcę świadomie okrutnego. Co więcej, nasuwa się pytanie o istotę Boga. Według Wierzbickiej: ten ktoś zawsze istnieje, czy zatem Bóg, który stworzył człowieka takiego jak On, jest wolny od zagłady? Ta wątpliwość rodzi kolejną, fundamentalną - czy jest Bogiem?

Bóg taki jak człowiek ma także ludzkie, negatywne cechy, takie jak: zazdrość, zakłamanie, okrucieństwo, które wykorzystuje przeciw stworzeniu. Zastosowanie ciągu prostych wypowiedzeń: wystarczy go przerazić, odbiorę bratu język brata, będa się zdradzać, ukazuje Boga, który działa nieetycznie, hołduje wartościom o silnym ładunku negatywnym, a są nimi strach i zdrada. Widać także, że najważniejszą wartością dla Boga jest samolubne panowanie nad światem (będą na mnie polegać, we mnie wierzyć).

Człowiek okłamywany przez Boga, wyrzucony z raju, uświadamia sobie również cynizm Stwórcy, wyrażony powtórzonym leksemem niewola (o silnej konotacji ujemnej):

(8) Wniewoli praw twych i ludzkiej niewoli

Żytem (112)

Prawa Boże, które Stwórca uznał za porzadek nie do zastapienia, przyniosły ludziom niewolę, pozbawiły ich myśli swobodnej. Istota buntująca się przeciw Bożym prawom zasługuje na karę. W ten sposób wyłania się kolejna konceptualizacja: Boga Sędziego.

\section{Bóg Sędzia}

Idiolektyczny obraz Boga Sędziego, pojawiający się w cyklu Raj, każe spojrzeć na Stwórcę w sposób odmienny od Jego obrazu zapisanego w Biblii i w nauczaniu Kościoła katolickiego $^{25}$. Cechą najważniejszą dla kategorii Boga Sędziego jest Jego sprawiedliwość26 i miłosierdzie ${ }^{27}$. Bóg Kaczmarskiego jest Sędzią, dla którego ważne jest tylko postuszeństwo

\footnotetext{
25 Por. Główne prawdy wiary: Bóg jest Sędzią sprawiedliwym, który za dobre wynagradza, a za złe karze.

${ }^{26}$ Zob. m.in. Ps 119, 137-138, 144; Iz 24,16; Mt 5, 6; 6, 33.

${ }^{27}$ Por. np. Przypowieść o synu marnotrawnym (Łk 15, 11-32).
} 
i uległość stworzenia. Bóg Sędzia przypomina przedstawiciela sądu systemu totalitarnego. Przejawia się to w zastosowaniu w odniesieniu do Boga Sędziego formy bezosobowej, oznajmującej wyrok nieposłusznym aniołom: Udowodniono wszystkim bunt / I wszyscy dziś będa straceni. Ten zabieg językowy kreuje postać Boga bezdusznego, okrutnego w swojej sprawiedliwości, który tworząc wolne stworzenie (myśli ma swobodne), jednocześnie nakazuje mu bezwzględne posłuszeństwo.

Konceptualizacja okrutnego sędziego rozwija się w dalszej części cyklu, poświęconej Sądowi Ostatecznemu. Służy temu określenie Wielki Oskarżyciel, w którym odbija się natura Boga potężnego, ale pozbawionego miłosierdzia. Definicja słownikowa podaje bowiem, że oskarżyciel to 'osoba składająca i popierająca w trakcie postępowania karnego żądanie ukarania oskarżonego'28. Moc Sędziego wyrażona jest językowo zarówno za pomocą ekspresywnych wyobrażeń Sądu Ostatecznego, jak i stosunku wszystkich sądzonych do niego (wszyscy dziś się ukorzyli):

(9) I wszystko widać równocześnie

Na ziemi płonie czarnym ogniem ludzkich powłok stos

A w jego tlustym wnętrzu walcza bestie

Sttumione Słońce spada $w$ dół nim cichnie pierwsza z trąb (118)

(10) Grzmi siódma trąba i widać już całego wiru oś

Pośrodku świata Wielki Oskarżyciel

A tłumy wokół Niego mkna i wznosza się pod strop

Lub z krzykiem przewalaja się w niebycie [...]

$W$ miliony dzieli ich na dwa obozy jeden głos

Przed którym wszyscy dziś się ukorzyli (119)

Niezwykłość i grozę destrukcji osiągnął poeta przez zastosowanie katastroficznej metaforyki i plastycznego oksymoronu. Warto zauważyć, że wizja czarnego ognia jest typowa dla obrazu piekła już od czasów staropolskich. Piekło było bowiem przestrzenią przepełnioną krzykami i jękami potępionych, ciemną otchłanią, w której ogień piekielny (pozbawiony blasku) stanowi najważniejsze źródło męki ${ }^{29}$.

Bóg Sędzia jest Bogiem zagłady swojego stworzenia. Nie ma już rajskiego świata. Kolejne głosy grzmiących trąb obwieszczają siedem etapów niszczenia (podobnie jak w Stworzeniu świata kolejne etapy tworzenia oznajmiały mijające dni). Wykreowany przez Kaczmarskiego obraz Sądu Ostatecznego przypomina wizje młodopolskie (zwłaszcza znane z Dies Irae Jana Kasprowicza). Ten sposób kategoryzacji Boga Sędziego jest niezgodny

\footnotetext{
${ }^{28}$ Stownik języka polskiego, red. Mieczysław Szymczak (Warszawa: PWN, 1982), t. II, 550.

${ }^{29}$ Por. Jacek Sokolski, Staropolskie zaświaty. Obraz piekła, czyśćca i nieba w renesansowej i barokowej literaturze polskiej wobec tradycji średniowiecznej (Wrocław: Wydawnictwo Uniwersytetu Wrocławskiego, 1994).
} 
z koncepcją Wierzbickiej (ten ktoś jest dobry). Należy jednak dodać, że o ile u Kasprowicza Bóg - groźny Sędzia - zostaje osądzony przez człowieka:

Nic co się stało pod sklepem niebiosów,

Bez Twej się woli nie stało!

$[\ldots]$

Przede mna przepaść zrodzona przez wine,

przez grzech Twój Boże!.... ${ }^{30}$

o tyle u Kaczmarskiego Bóg - groźny Sędzia - zmienia się w konceptualizację Boga samotnego.

\section{Bóg samotny}

Ta niestereotypowa cecha Boga wiąże się z Jego atrybutem Boga sprawiedliwego, który karze za brak posłuszeństwa, pokory, uległości (będących warunkiem nie do zastapienia). Utwory Stracenie aniołów i Wygnanie z raju pokazują karę wymierzoną zbuntowanym aniołom i niewiernym ludziom. Tą karą jest pozbawienie ich raju. Kara ta straszna jest jednak nie tylko dla ukaranych, ale również dla Boga Sędziego, który sam siebie skazał na samotność.

Wizja pustego raju zmienia konceptualizację samego Boga:

(11) W pustym raju dni po wygnaniu

Stwórca trawi na dtugich spacerach

Noca leży na chmurnym postaniu

Jasność wtasna sen mu odbiera

Swoich praw się uczy na pamięć

Sam ich musi przestrzegać by trwały [...]

Pusty raj jest dla Stwórcy za mały (109)

Rozpoczynający utwór epitet pusty raj uświadamia odbiorcy samotność Boga. Ciąg wypowiedzeń pokazujących jego zajęcia: dni [...] trawi na dtugich spacerach; leży na chmurnym postaniu; swoich praw uczy się na pamięć wartościuje Jego nową rzeczywistość - jego życie jest nudne, pozbawione sensu. Warto też podkreślić, że Bóg stał się niewolnikiem własnych praw. Użycie normatywnego wyrażenia musi przestrzegać (swoich praw) wynika z pierwotnego rozporządzenia Boga Stwórcy o porządku nie do zastapienia. Bóg jest tu wyraźnie antropomorfizowany, a jego działania nie różnią się od normalnego życia każdego

${ }^{30}$ Jan Kasprowicz, Poezje 2. Dzieła wybrane II, red. Jan Józef Lipski (Kraków: Wydawnictwo Literackie, 1958). 
śmiertelnika. O jego boskości świadczą tylko metaforyczne opisy: Noca leży na chmurnym posłaniu; Jasność własna sen mu odbiera. Ten Bóg nie mówi już o sobie i własnej doskonałości (brak tu form w pierwszej osobie liczby pojedynczej). Bóg samotny opisywany jest tylko z perspektywy obserwatora w trzeciej osobie liczby pojedynczej.

Bóg nie został co prawda zupełnie sam, towarzyszą mu bowiem ci, którzy się nie zbuntowali - aniołowie. Jednak ich towarzystwo nie daje Bogu radości:

(12) W pustym raju archaniot Gabriel [...]

Towarzyszy Stwórcy w przechadzkach

Lecz nie może Go bawić rozmowa

Żadna myśla zaskoczyć znienacka

Obaj myślą wszak jednakowo (109)

Pokora, posłuszeństwo i uległość, których aniołowie nie odrzucili, czynią z nich istoty wierne, ale nieprzydatne Bogu w walce $\mathrm{z}$ trawiącą go samotnością. Tym samym dochodzi do przewartościowania postaw, które Bóg Stwórca uznał za najważniejsze. Istota harmonijnego życia w raju stała się dla Boga samotnego przekleństwem. Zastosowanie zdania przeciwstawnego (Towarzyszy Stwórcy w przechadzkach / Lecz nie może Go bawić rozmowa) ma na celu ukazanie beznadziejności sytuacji, którą zazdrosny o swoją wszechwładzę Bóg sam sobie zgotował. Nie dziwi więc kolejny obraz Boga skazańca:
(13) W pustym raju czas przejąt władanie
Stwórca czeka z rękami wzdtuż ciała
Panujacy światu skazaniec
Dożywocie wytącznej chwaty [...]
W pustym raju cokolwiek się stanie
Zawsze stanie się przeciw Niemu (109)

Stereotypowy obraz Boga Króla zostaje tu podwójnie zakłócony. Bóg Król, wymagający od stworzenia czci i pokory, stał się Królem - skazańcem dożywocia wyłącznej chwały. Warto zwrócić uwagę zwłaszcza na ostatnie wyrażenie, w którym leksem chwała konotowany jest ujemnie przez zestawienie z oznaczającym surową karę leksemem dożywocie oraz przymiotnikiem wyłączna, podkreślającym Bożą godność, a jednocześnie osamotnienie.

Bóg utracił jednak atrybuty wszechmocy i wszechwiedzy. Zastosowanie metafory czas przejął władanie i obrazu Stwórcy czekającego z opuszczonymi rękami kreuje obraz Boga słabego, bezsilnego, oczekującego na zło, które musi nadejść. Bóg nie jest już wszechwiedzący i wszechwładny, nie wie, co będzie i kiedy (bo czas przejął władzę nad pustym rajem), wie tylko, że stanie się przeciw Niemu. 
Taka konceptualizacja ostatecznie kłóci się z pojmowaniem Boga chrześcijańskiego, a także koncepcją Anny Wierzbickiej, w której Bóg to ktoś, od czyjej woli wszystko zależy. Zatem Bóg samotny traci najważniejszy atrybut swojej boskości - wolę sprawczą.

\section{Wnioski}

Podsumowując należy stwierdzić, że kreacja Boga w Raju Jacka Kaczmarskiego pozornie opiera się na koncepcji Boga chrześcijańskiego. Można więc wyodrębnić w tym utworze kilka stereotypowych konceptualizacji Boga: Stwórcy, Króla, Sędziego. Katalog Jego podstawowych cech w tekstach, które zostały poddane analizie, jest tylko częściowo zbieżny ze zbiorem atrybutów Najwyższego w ujęciu katechizmowym i potocznym. Należą do nich: doskonałość i stwórczość. Pozostałe cechy: miłość, dobroć, istotowa odrębność, a nawet wieczność przypisywane są Bogu tylko pozornie. Jego wizja władzy (oparta na posłuszeństwie, uległości i pokorze) powoduje, że Bóg staje się najpierw bezdusznym (pozbawionym miłości) Sędzią wypędzającym z raju wszystkich buntowników (anioły i ludzi), a w czasie Sądu Ostatecznego staje się Wielkim Oskarżycielem, żądnym kary dla stworzenia.

Taka konceptualizacja Boga jako Króla i Sędziego doprowadza do pojawienia się nowej kategorii - Boga samotnego, skazanego na dożywotnią (wieczną?) samotność w pustym raju, pozbawionego atrybutów boskości.

Język kształtujący idiolektalny obraz Boga u Jacka Kaczmarskiego jest raczej prosty. Autor opisuje najważniejsze dla Stwórcy i stworzenia wydarzenia za pomocą nieskomplikowanej, choć nacechowanej aksjologicznie leksyki, prostej składni oraz na ogół niewyszukanych środków stylistycznych. Warto zauważyć, że mówienie o sferze sacrum wiąże się na ogół ze stosowaniem stylu wysokiego, patetycznego, z hieratycznością stylu ${ }^{31}$. Język stosowany przez Kaczmarskiego pozbawiony jest typowych cech języka religijnego. W opisie dzieła stworzenia Bóg mówi o sobie w pierwszej osobie liczby pojedynczej, a nie w typowej formie pluralis maiestatis. Poeta zastosował również formę bezosobową, w której przedstawiony został wyrok Boga. Najciekawsze są środki językowe opisujące Sąd Ostateczny. Zwracają uwagę zwłaszcza ekspresyjne metafory i barwne epitety.

Należy zauważyć, że taka konceptualizacja Boga u Kaczmarskiego wiąże się z jego koncepcją władzy totalitarnej (tworzącej nowy ład, panującej zniewolonemu narodowi i sądzącej niepokornych). W tym kontekście obraz Boga samotnego, świadomego swojej porażki, ma dać nadzieję odbiorcom na nadejście nowych, lepszych czasów.

${ }^{31}$ Maria Wojtak, ,Styl religijny w perspektywie genologicznej”, w: Język religijny dawniej i dziś. Materiaty z konferencji. Gniezno 15-17 kwietnia 2002, red. Stanisław Mikołajczak, ks. Tomasz Węcławski (Poznań: Wydawnictwo UAM, 2004), 111. 


\section{Wykaz skrótów}

KKK - Katechizm Kościoła Katolickiego.

\section{Bibliografia}

\section{Źródło}

Kaczmarski, Jacek. Antologia poezji, red. Krzysztof Nowak. Warszawa: Demart, 2012.

Bartmiński, Jerzy. „Podstawy lingwistycznych badań nad stereotypem - na przykładzie stereotypu matki”. W: Język a Kultura 12: Stereotyp jako przedmiot lingwistyki. Teoria, metodologia, analizy empirycz$n e$, red. Janusz Anusiewicz, Jerzy Bartmiński. Wrocław: Wydawnictwo Uniwersytetu Wrocławskiego, 1998, 63-83.

Kadyjewska, Anna. „Problematyka obrazu świata w badaniach języka pisarza na przykładzie pism Cypriana Norwida". W: Semantyka tekstu artystycznego, red. Anna Pajdzińska, Ryszard Tokarski. Lublin: Wydawnictwo UMCS, 2001, 321-332.

Karpluk, Maria. „O najwcześniejszym polskim słownictwie chrześcijańskim”. W: O języku religijnym. Zagadnienia wybrane, red. Maria Karpluk, Jadwiga Sambor. Lublin: Wydawnictwo Katolickiego Uniwersytetu Lubelskiego, 1988, 89-101.

Karpluk, Maria. „O staropolskiej terminologii chrześcijańskiej (inspiracje czeskie)”. W: Tysiąc lat polskiego słownictwa religijnego, red. Bogusław Kreja. Gdańsk: Wydawnictwo Uniwersytetu Gdańskiego, 1999, 29-33.

Kasprowicz, Jan. Poezje 2. Dzieła wybrane, wyd. II, red. Jan Józef Lipski. Kraków: Wydawnictwo Literackie, 1958.

Katechizm Kościoła Katolickiego, Poznań: Wydawnictwo Pallotinum, 1994.

Kępka, Izabela. „Gdy królewską godność zachowały tylko kamienne lwy..., czyli o językowej kreacji lwa w piosenkach Jacka Kaczmarskiego". Poznańskie Studia Polonistyczne. Seria Językoznawcza 24 (2017), 2: 59-72.

Kępka, Izabela. „Językowa kreacja psa i jej funkcje w poezji Jacka Kaczmarskiego”. Studia Językoznawcze. Synchroniczne i diachroniczne aspekty badań polszczyzny, 16 (2017): 135-138.

Klich, Edward. Polska terminologia chrześcijańska. Poznań: Poznańskie Towarzystwo Przyjaciół Nauk, 1927.

Kopaliński, Władysław. Stownik symboli, wyd. II. Warszawa: Wiedza Powszechna, 1991.

Kostkiewiczowa, Teresa. „Jak poeci polscy drugiej połowy XVIII wieku mówili o Bogu i szatanie”. W: Tysiac lat polskiego słownictwa religijnego, red. Bogusław Kreja. Gdańsk: Wydawnictwo Uniwersytetu Gdańskiego, 1999, 83-98.

Kowalewska-Dąbrowska, Jolanta. Językowy obraz Boga i człowieka w poezji Jana Twardowskiego. Gdańsk: Wydawnictwo Uniwersytetu Gdańskiego, 2006.

Pajdzińska, Anna. „Językowy obraz Boga i szatana w polskiej poezji powojennej”. W: Tysiąc lat polskiego stownictwa religijnego, red. Bogusław Kreja. Gdańsk: Wydawnictwo Uniwersytetu Gdańskiego, 1999, 157-178.

Pismo Święte Starego i Nowego Testamentu w przekładzie z języków oryginalnych. Opracował zespół biblistów polskich z inicjatywy benedyktynów tynieckich, wyd. III. Poznań-Warszawa: Wydawnictwo Pallotinum, 1980. 
Piwińska, Marta. „Bóg utracony, Bóg odnaleziony”. W: Problemy polskiego romantyzmu I, red. Maria Żmigrodzka, Zofia Lewinówna. Wrocław: Zakład Narodowy im. Ossolińskich, Wydawnictwo Naukowe PAN, 1971, 251-301.

Podraza-Kwiatkowska, Maria. „Obraz Boga wśród światopoglądowych przemian Młodej Polski”. W: Tysiąc lat polskiego słownictwa religijnego, red. Bogusław Kreja. Gdańsk: Wydawnictwo Uniwersytetu Gdańskiego, 141-155.

Puzynina, Jadwiga. „Językowy obraz Boga w poezji romantycznej”. W: Tysiąc lat polskiego stownictwa religijnego, red. Bogusław Kreja. Gdańsk: Wydawnictwo Uniwersytetu Gdańskiego, 99-115.

Rzepka, Wojciech Ryszard, Bogdan Walczak. „Bóg i szatan w polszczyźnie XVI wieku”. W: Tysiac lat polskiego stownictwa religijnego, red. Bogusław Kreja. Gdańsk: Wydawnictwo Uniwersytetu Gdańskiego, 57-66.

Skorupska-Raczyńska, Elżbieta. Kreacja ojca w powieściach nadniemeńskich Elizy Orzeszkowej (studium językowo-stylistyczne). Gorzów Wielkopolski-Szczecin: Wydawnictwo Naukowe Wyższej Szkoły Zawodowej, 2013.

Skubalanka, Teresa. „Językowa kreacja Jacka Soplicy (Księdza Robaka)”. W: taż, Mickiewicz, Słowacki, Norwid. Studia nad językiem i stylem. Lublin: Wydawnictwo UMCS, 1997.

Słownik języka polskiego, red. Mieczysław Szymczak. Warszawa: PWN, 1982.

Sokolski, Jacek. Staropolskie zaświaty. Obraz piekła, czyśćca i nieba w renesansowej i barokowej literaturze polskiej wobec tradycji średniowiecznej. Wrocław: Wydawnictwo Uniwersytetu Wrocławskiego, 1994.

Strykowska, Monika. „Obraz Boga w Rytmach Mikołaja Sępa Szarzyńskiego na tle prądów ideowych epoki”. W: Tysiąc lat polskiego stownictwa religijnego, red. Bogusław Kreja. Gdańsk: Wydawnictwo Uniwersytetu Gdańskiego, 67-82.

Wierzbicka, Anna. Kocha, lubi, szanuje. Medytacje semantyczne. Warszawa: Wiedza Powszechna, 1971.

Wierzbicka, Anna. Co mówi Jezus? Objaśnienia przypowieści ewangelicznych w stowach prostych i uniwersalnych, przeł. Izabela Duraj-Nowosielska. Warszawa: Wydawnictwo Naukowe PWN, 2002.

Wojtak, Maria. „Styl religijny w perspektywie genologicznej”. W: Język religijny dawniej i dziś. Materiaty $z$ konferencji. Gniezno 15-17 kwietnia 2002, red. Stanisław Mikołajczak, ks. Tomasz Węcławski. Poznań: Wydawnictwo UAM, 2004, 104-113.

\section{Źródlo internetowe}

Katechizm Kościoła Katolickiego, Poznań: Wydawnictwo Pallotinum, 1994. Dostęp 25.05.2018, http:// www.archidiecezja.pl/include/user_file/kkk.pdf.

\section{Obraz Boga w Raju Jacka Kaczmarskiego}

Streszczenie

Celem artykułu jest ukazanie językowej kreacji Boga w spektaklu Raj Jacka Kaczmarskiego. Wykorzystano w nim metodologię związaną z badaniem językowej kreacji świata w tekstach literackich. Analiza materiału wyekscerpowanego z utworów miała pokazać, w jaki sposób Kaczmarski ukazuje Boga i czy Jego kreacja jest zgodna z ogólnie przyjętym pojmowaniem Istoty Najwyższej. Wyodrębniono stereotypowe konceptualizacje Boga: Króla, Sędziego. Boga wykreowanego przez Kaczmarskiego cechuje doskonałość i stwórczość. Pozbawiony jest natomiast innych cech zwyczajowo mu przypisywanych: dobroci, miłości, istotowej odrębności i wieczności. Podczas Sądu Ostatecznego bezduszny Bóg, pozbawiony miłości do ludzi, staje 
się Wielkim Oskarżycielem człowieka. W konsekwencji staje się Bogiem samotnym, skazanym na dożywotnią samotność. Taka kreacja Boga u Kaczmarskiego wiąże się z jego koncepcją władzy totalitarnej. W tym kontekście obraz Boga samotnego, świadomego swojej porażki, ma dać nadzieję odbiorcom na nadejście nowych, lepszych czasów.

\section{The image of God in Raj ("Paradise") by Jacek Kaczmarski}

\section{Su m m ary}

The article presents the linguistic creation of God in the play Raj ("Paradise") written by Jacek Kaczmarski and is based on the method used in research into linguistic creation of worlds in literary texts. The analysis of the excerpted material was to show in which way Kaczmarski presented God and whether his creation was in accordance with the stereotypical concept of the Supreme Being. Stereotypical conceptualisations of God has been identified: King and Judge. The God created by Kaczmarski is perfect. However, he is deprived of other features that are stereotypically attributed to him: goodness, love, essential identity and eternity. During the Final Judgement the heartless God deprived of any pity for people becomes an indicter of the human being. Consequently, he becomes a lonely God, condemned to perpetual solitude. Such an image of God created by Kaczmarski results from his concept of totalitarian power. In this context the image of a lonely God, aware of his failure, is supposed to give hope that better times will come.

Cytowanie

Kępka, Izabela. Obraz Boga w Raju Jacka Kaczmarskiego. Studia Językoznawcze. Synchroniczne i diachroniczne aspekty badań polszczyzny 18 (2019): 75-89. DOI: 10.18276/sj.2019.18-06. 